\title{
Características de produção e qualidade nutricional de genótipos de capim- colonião colhidos em três estádios de maturidade ${ }^{1}$
}

\author{
Samuel dos Santos Stabile ${ }^{2}$, Diego Reynaga Salazar ${ }^{2}$, Liana Jank ${ }^{3}$, Francisco Palma Rennó ${ }^{2}$ \\ Luís Felipe Prada e Silva ${ }^{2}$ \\ 1 Pesquisa Financiada pela Fundação de Amparo à Pesquisa do Estado de São Paulo (FAPESP).
2 Departamento de Nutrição e Produção Animal - FMVZIUSP, Av. Duque de Caxias Norte, 225, CEP: 13.635-900, Pirassununga, SP.
${ }^{3}$ Embrapa Gado de Corte, Campo Grande, MS.
}

RESUMO - Objetivou-se verificar a existência de variação genética entre cultivares de capim-colonião quanto ao efeito da maturidade sobre a composição química e a digestibilidade, e classificar os genótipos de acordo com características produtivas e de qualidade nutricional. Utilizou-se o delineamento de blocos ao acaso, com parcelas subdivididas e três repetições, considerando parcelas as datas de corte e subparcelas, os genótipos. A produção de MS diferiu entre os genótipos somente aos 90 dias de crescimento, mas a porcentagem de folhas, colmos e material morto variou tanto aos 60 como aos 90 dias de crescimento. Ao contrário do observado para as folhas, a composição química e a digestibilidade do colmo apresentou grande variabilidade entre os genótipos. O colmo apresentou concentrações mais elevadas de FDN, FDA e lignina e menores valores de PB em comparação às folhas. Apresentou ainda maior digestibilidade da MS aos 60 dias de crescimento e maior digestibilidade da FDN aos 30 e 60 dias de crescimento. No agrupamento dos cultivares, os genótipos PM39 e PM47 foram apontados como os mais promissores no programa de melhoramento, por apresentarem alta produtividade e alta qualidade nutricional. A maturidade pouco afeta a digestibilidade de folhas em comparação ao colmo. Quando a participação de colmo no total de massa seca aumenta, esse componente passa a ser o limitador da qualidade de plantas forrageiras. Portanto, programas de melhoramento devem considerar, além da relação folha:colmo, também a digestibilidade in vitro da FDN do colmo na seleção de genótipos.

Palavras-chave: digestibilidade, gramíneas tropicais, lignina, nutrição animal, Panicum maximum, parede celular

\section{Characteristics of nutritional quality and production of genotypes of guineagrass harvested in three maturity stages}

\begin{abstract}
This study aimed to verify the existence of genetic variation among guineagrass cultivars regarding the effect of maturity on chemical composition and digestibility, and to classify the genotypes according to productive characteristics and nutritional quality. A randomized block design, with split-plots and three replications, was used. Dates of the cuts were considered as the plots, and the genotypes were considered as the sub-plots. Dry matter yield differed among the genotypes only at 90 days of growth, but the percentage of leaves, stems, and senesced material changed at 60 days of growth, as well as at 90 days of growth. Differently from what was observed for the leaves, chemical composition and digestibility of stem showed great variability among genotypes. The stem showed higher concentrations of neutral detergent fiber, acid detergent fiber, and lignin, and lower values of crude protein, when compared to the leaves. It also presented higher digestibility of dry matter at 60 days of growth, and higher digestibility of neutral detergent fiber at 30, and at 60 days of growth. Clustering of the cultivars identified the PM39 and PM47 genotypes as the most promising ones in the breeding program, because they showed high productivity and high nutritional quality. Maturity has little effect on leaf digestibility when compared to the stem. When participation of the stem increases in the total of dry matter, this component becomes the major factor limiting quality of forage plants. Therefore, breeding program must consider, in addition to leaf:stem ratio, the in vitro digestibility of neutral detergent fiber of the stem when selecting genotypes.
\end{abstract}

Key Words: animal nutrition, cell wall, digestibility, lignin, Panicum maximum, tropical grasses

\section{Introdução}

No Brasil, a produção de bovinos de corte ocorre predominantemente a pasto, onde as pastagens tropicais são as principais fontes de alimento para os ruminantes, sendo sensivelmente mais econômica em relação aos concentrados (Aguiar et al., 2000). O Panicum maximum é uma das espécies de plantas forrageiras mais importantes 
para a produção de bovinos nas regiões de climas tropical e subtropical (Souza, 1999), principalmente devido ao potencial para grande produtividade, em especial na época das águas (Difante et al., 2009).

A eficiência da utilização das plantas forrageiras pelos animais está na dependência da qualidade e da quantidade de forragem disponível na pastagem e do potencial do animal (Reis \& Rodrigues, 1993). Apesar da grande produtividade das gramíneas tropicais, à medida que vai avançando o desenvolvimento vegetal ocorre drástica diminuição do teor proteico e aumento do teor de fibra, associado ao aumento no teor de lignina, limitando a produção de carne e leite (Euclides, 2001). A lignina forma uma barreira que impede a hidrólise enzimática da celulose e da hemicelulose, limitando a digestão da parede celular de forragem (Rodrigues et al., 2004).

A relação entre lâminas e colmos é parâmetro importante na avaliação da qualidade das plantas forrageiras, sobretudo em razão das folhas apresentarem melhor valor nutricional, afetando, dessa forma, o consumo voluntário dos animais (Rodrigues, 1986; Herrera, 1979; Hacker \& Minson, 1981),

A digestibilidade da fração fibrosa é fundamental na avaliação da qualidade das plantas forrageiras, já que as frações não digeríveis ocupam o trato digestivo, reduzindo o espaço ruminal e o consumo de matéria seca (Thiago \& Gill, 1990). Assim, o desempenho de animais em pasto depende não só da quantidade de parede celular, mas também de sua digestibilidade.

Objetivou-se verificar a existência de variação genética entre cultivares de Panicum maximum quanto ao efeito da maturidade sobre a composição química e a digestibilidade de colmo e folhas, e classificar os genótipos em grupos de acordo com características produtivas e de qualidade nutricional.

\section{Material e Métodos}

O experimento foi implantado no município de Campo Grande, Mato Grosso do Sul (latitude $20^{\circ} 26^{\prime}$ S e longitude $\left.54^{\circ} 43^{\prime} \mathrm{W}\right)$. A altura local é de 530,7 m, o solo é do tipo Neossolo (EMBRAPA, 1999) e o padrão climático da região é descrito, segundo Köppen, na faixa de transição entre Cfa e Aw tropical úmido. A precipitação média anual é de $1500 \mathrm{~mm}$, sendo considerados meses de seca de maio a setembro (30\% da precipitação anual).

Foi estabelecido ensaio de avaliação de onze genótipos de capim-colonião: cultivares Massai, Milênio, Mombaça e Tanzânia, e genótipos PM39, PM40, PM41, PM44, PM45, PM46 e PM47 em área da Embrapa Gado de Corte. As parcelas foram adubadas com $100 \mathrm{~kg} / \mathrm{ha} \mathrm{de} \mathrm{N}$ (ureia), $100 \mathrm{~kg} / \mathrm{ha}$ de $\mathrm{P}_{2} \mathrm{O}_{5}$ (superfosfato simples) e $100 \mathrm{~kg} /$ ha de $\mathrm{K}_{2} \mathrm{O}$ (cloreto de potássio). Após corte de nivelamento a $20 \mathrm{~cm}$ do solo, no dia 29 de dezembro de 2005, as parcelas foram colhidas com 30, 60 e 90 dias de crescimento, sendo a primeira coleta no dia $1^{\underline{0}}$ de fevereiro, a segunda coleta no dia $1^{\underline{0}}$ de março e a terceira coleta no dia $1^{0}$ de abril de 2006.

As parcelas foram formadas por seis linhas espaçadas de 0,5 metro (m) por quatro metros de comprimento, em um total de $10 \mathrm{~m}^{2}$ por parcela. A cada data de corte, duas linhas foram cortadas a aproximadamente $20 \mathrm{~cm}$ do solo, para avaliação da produção de massa, da relação folha:colmo e da composição bromatológica. A condição climática manteve-se no padrão da época, sem ocorrência de falta de água por período prolongado (Tabela 1).

Após o corte das duas linhas, as amostras foram pesadas e uma sub-amostra de aproximadamente $1,5 \mathrm{~kg}$ foi retirada, pesada e separada em lâminas foliares (fração folhas), bainhas foliares e colmos (fração colmo) e material senescido (fração morto). As subamostras foram acondicionadas em sacos plásticos e permaneceram congeladas a $-20^{\circ} \mathrm{C}$ para posterior análise. As amostras foram secas em estufa com ventilação forçada de ar a $55^{\circ} \mathrm{C}$, por 72 horas, para estimativa inicial da matéria seca. As amostras secas foram moídas com peneira de malha de $1 \mathrm{~mm}$ e posteriormente analisadas para determinação da $\mathrm{MS}$ total, em estufa a $105^{\circ} \mathrm{C}$ por 24 horas.

De posse do peso total da amostra e dos teores de matéria seca (MS), determinou-se a produção total de matéria seca verde (MSV) somando-se as produções de MS de folhas e colmos, ou seja, descontando-se a produção de MS de material morto (Barbosa et al., 2002).

Os teores de proteína bruta (PB) foram analisados segundo AOAC (1980) e os teores de fibra em detergente neutro (FDN), fibra em detergente ácido (FDA) e lignina

Tabela 1 - Temperatura e precipitação pluviométrica na região de Campo Grande, Mato Grosso do Sul, no período de 29/12/2005 a $1 / 4 / 2006$

\begin{tabular}{|c|c|c|c|}
\hline Período & $29 / 12 / 2005$ a $1 / 2 / 2006$ & $2 / 2 / 2006$ a $1 / 3 / 2006$ & $2 / 3 / 2006$ a $1 / 4 / 2006$ \\
\hline Temperatura média $\left({ }^{\circ} \mathrm{C}\right)$ & 25,5 & 24,9 & 25,1 \\
\hline Precipitação acumulada (mm) & 149,3 & 178,3 & 141,2 \\
\hline
\end{tabular}

Fonte: EMBRAPA-CNPGC. 
seguiram a metodologia de Goering \& Van Soest (1970). As frações colmo e folha foram analisadas para digestibilidade in vitro da matéria seca (DIVMS) e digestibilidade in vitro da fibra detergente neutro (DIVFDN), conforme metodologia originalmente descrita por Goering \& Van Soest (1970). O fluido ruminal foi coletado de três vacas mantidas a pasto recebendo suplementação mineral. As amostras foram incubadas por 30 horas a $39^{\circ} \mathrm{C}$ em estufa de temperatura controlada. Durante esse tempo, os frascos foram agitados três vezes por dia. Ao final do período de incubação, os frascos foram removidos da estufa, adicionam-se $20 \mathrm{~mL}$ de solução detergente neutro e foram mantidos estocados a $20^{\circ} \mathrm{C}$ para análise posterior do teor de fibra em detergente neutro segundo Goering \& Van Soest (1970).

Os dados foram analisados considerando-se o delineamento de blocos ao acaso, em esquema de parcela subdividida, sendo a data de corte (maturidade) a parcela e os genótipos, as subparcelas. A análise estatística foi realizada utilizando-se o procedimento MIXED do software SAS (SAS, 2000) segundo o modelo: $\mathrm{Y}=\mu+$ genótipos + maturidade + bloco + maturidade $\times$ bloco $+\mathrm{e}$, onde os termos bloco e maturidade $\times$ bloco foram considerados como aleatórios.

$\mathrm{Na}$ presença de interação bloco por maturidade $\times$ genótipos, as médias dos genótipos em cada idade de corte foram comparadas utilizando-se o teste-t protegido por Fisher a 5\% de probabilidade (Steel \& Torrie, 1980). O estudo das correlações entre digestibilidade de colmo e folhas e componentes químicos da parede celular foi realizado de acordo com o procedimento PROC CORR (SAS, 2000).
Após a obtenção dos resultados laboratoriais, procedeu-se a redução dos valores à média dos genótipos, empregando-se a produção de matéria seca verde (MSV), digestibilidade in vitro da fibra em detergente neutro (DIVFDN) do colmo e a porcentagem de folhas na matéria seca com 90 dias de crescimento como base para análise multivariada de agrupamento por otimização, segundo o método de Tocher (Cruz \& Regazzi, 1997). Adotou-se a distância euclidiana média como medida básica de dissimilaridade, calculada após a padronização das informações.

\section{Resultados e Discussão}

Nos genótipos de capim-colonião, o aumento linear na produção de matéria seca verde está relacionado à elongação do colmo, tendo em vista a redução média de $91,1 \%$ para $54,1 \%$ de participação da massa de folhas na massa total quando os genótipos foram colhidos com 30 e 90 dias (Tabela 2). A produção de matéria seca verde foi diferente entre os genótipos somente quando colhidos com 90 dias de crescimento (Tabela 2). Houve interação significativa $(\mathrm{P}<0,05)$ entre maturidade $\times$ genótipos para produção de matéria seca verde, porcentagem de folhas, colmo e material morto. A produção de matéria seca verde diferiu entre os genótipos somente quando foram colhidos aos 90 dias de crescimento (Tabela 2).

A produção total de matéria seca verde com 90 dias de crescimento variou de $9035 \mathrm{~kg} / \mathrm{ha}$ a $22.857 \mathrm{~kg} / \mathrm{ha}$, para os genótipos PM45 e Mombaça, respectivamente (Tabela 2).

Tabela 2 - Produção de matéria seca verde e proporção de componentes da planta de 11 genótipos de capim-colonião colhidos em três idades de corte

\begin{tabular}{|c|c|c|c|c|c|c|c|c|c|c|c|c|}
\hline \multirow[b]{2}{*}{ Dias de crescimento ${ }^{2}$} & \multicolumn{3}{|c|}{$\begin{array}{l}\text { Produção de matéria } \\
\text { seca verde }(\mathrm{kg} / \mathrm{ha})\end{array}$} & \multicolumn{3}{|c|}{ Folhas (\%MS) } & \multicolumn{3}{|c|}{ Colmos (\%MS) } & \multicolumn{3}{|c|}{ Material morto (\%MS) } \\
\hline & 30 dias & 60 dias & 90 dias & 30 dias & 60 dias & 90 dias & 30 dias & 60 dias & 90 dias & 30 dias & 60 dias & 90 dias \\
\hline Milênio & 4467 & 7014 & 18.238AB & 91,6 & $70,8 \mathrm{C}$ & $50,2 \mathrm{BCD}$ & 8,4 & 25,8A & $41,7 \mathrm{~A}$ & - & 3,4D & $8,1 \mathrm{EF}$ \\
\hline Mombaça & 3938 & 4432 & $22.857 \mathrm{~A}$ & 96,0 & $81,9 \mathrm{AB}$ & 50,9BCD & 4,0 & 14,6BCD & $41,5 \mathrm{~A}$ & - & $3,5 \mathrm{D}$ & $7,7 \mathrm{~F}$ \\
\hline Tanzânia & 3294 & 3734 & 14.907BCD & 84,3 & $76,7 \mathrm{BC}$ & $47,0 \mathrm{D}$ & 15,7 & 9,8CD & $33,9 \mathrm{AB}$ & - & $13,4 \mathrm{~A}$ & 19,1ABC \\
\hline PM41 & 3209 & 5274 & 13.012BCD & 91,7 & $80,3 \mathrm{AB}$ & $63,2 \mathrm{AB}$ & 8,3 & $14,0 \mathrm{BCD}$ & 25,2BC & - & $5,7 \mathrm{BCD}$ & 11,6DEF \\
\hline PM44 & 3118 & 5003 & 12.160BCD & 88,9 & 71,6C & $47,6 \mathrm{D}$ & 11,1 & $19,4 \mathrm{AB}$ & $37,9 \mathrm{AB}$ & - & $9,0 \mathrm{ABC}$ & $14,6 \mathrm{BCDE}$ \\
\hline PM45 & 3319 & 4355 & 9035D & 94,9 & $83,1 \mathrm{AB}$ & $61,3 \mathrm{ABC}$ & 5,1 & $7,1 \mathrm{D}$ & $16,4 \mathrm{C}$ & - & $9,8 \mathrm{AB}$ & $22,3 \mathrm{~A}$ \\
\hline PM46 & 2079 & 5893 & 12.580BCD & 90,0 & 71,4C & $45,1 \mathrm{D}$ & 10,0 & $24,1 \mathrm{~A}$ & $32,9 \mathrm{AB}$ & - & $4,5 \mathrm{CD}$ & $22,0 \mathrm{~A}$ \\
\hline PM47 & 2876 & 5701 & 11.047D & 91,7 & $77,6 \mathrm{BC}$ & 51,9BCD & 8,3 & $18,1 \mathrm{ABC}$ & $28,5 \mathrm{ABC}$ & - & $4,2 \mathrm{CD}$ & $19,7 \mathrm{AB}$ \\
\hline Média & $3186 c$ & $5223 b$ & $14.152 \mathrm{a}$ & $91,1 \mathrm{a}$ & $78,6 b$ & 54,1c & $8,9 c$ & $14,8 b$ & $30,7 \mathrm{a}$ & - & $6,5 b$ & $15,1 \mathrm{a}$ \\
\hline
\end{tabular}

${ }^{1}$ PMSV: produção de matéria seca verde, em kg/ha. ${ }^{2}$ Dias de crescimento: dias de crescimento da planta, contados a partir de corte de nivelamento em 29/12/2005. ${ }^{3}$ EPM: erro-padrão da média. ${ }^{3}$ Probabilidade de efeito significativo de genótipo (teste $\mathrm{F}$ ). ns não-significativo; ${ }^{*} \mathrm{P}<0,05 ; * * \mathrm{P}<0,01$. ABCDEF - Médias com letras maiúsculas diferentes na mesma coluna diferem segundo o teste t protegido por Fisher. abc - Médias com letras minúsculas diferentes na mesma linha diferem pelo teste Tukey. 
Entre os cultivares avaliados, o capim-mombaça apresentou maior produção de matéria seca verde com 90 dias do que os cultivares Massai e Tanzânia, e similar ao cultivar Milênio (Tabela 2). A maior produção do capim-mombaça frente aos demais cultivares de Panicum maximum foi verificada em outros experimentos (Jank et al., 1994).

Quanto à proporção de folhas, houve diferença entre os genótipos quando colhidos com 60 ou 90 dias de crescimento (Tabela 2). Dentre oos cultivares testados, o Massai apresentou o menor alongamento de colmos com o avanço da maturidade, mantendo $70,7 \%$ de folhas na matéria seca verde quando colhido com 90 dias, em comparação a aproximadamente $50 \%$ de folhas dos outros três cultivares avaliados (Tabela 2). A maior proporção de folhas do cultivar Massai em relação aos demais cultivares de $P$. maximum está de acordo com resultados anteriores (Brâncio et al., 2003; Euclides et al., 2008).

Cecato et al. (2000) também não encontraram diferença no percentual de lâmina foliar dos cultivares Tanzânia e Mombaça e obtiveram valores muito semelhantes aos desta pesquisa. Já Quadros et al. (2002) relataram pequeno aumento na porcentagem de folhas do capim-mombaça quando comparado ao capim-tanzânia (54\% e 51\%), ambos com 55-65 dias de crescimento, e relataram valores inferiores ao deste experimento.

A porcentagem média de material morto chegou a 15,1\% com 90 dias de crescimento, sendo que houve diferença significativa entre os genótipos quando colhidos com 60 ou 90 dias de crescimento (Tabela 2). Os cultivares Milênio e Mombaça apresentaram as menores porcentagens de material morto, dentre os cultivares avaliados.

O teor de matéria seca do colmo dos genótipos aumentou linearmente com a maturidade, passando de $12,9 \%$ para $23,7 \%$, quando colhidos com 30 ou 90 dias, respectivamente (Tabela 3). Houve diferença entre os genótipos em relação ao teor de MS do colmo somente quando colhidos com 30 dias de crescimento (Tabela 3). O teor de fibra em detergente neutro do colmo aumentou linearmente com a maturidade, sendo que os genótipos só diferiram entre si quando colhidos com 30 dias de crescimento (Tabela 3). Dentre os cultivares testados, o cultivar Massai apresentou maior teor de fibra em detergente neutro do colmo com 30 dias de crescimento do que os cultivares Milênio e Mombaça, e não diferiu do cultivar Tanzânia (Tabela 3).

Não houve diferença entre os genótipos quanto ao teor de proteína bruta do colmo nas três idades de corte. Em relação à média dos teores de proteína bruta do colmo, não houve diferença entre 30 e 60 dias de idade e ocorreu queda acentuada dos 60 para os 90 dias de maturidade

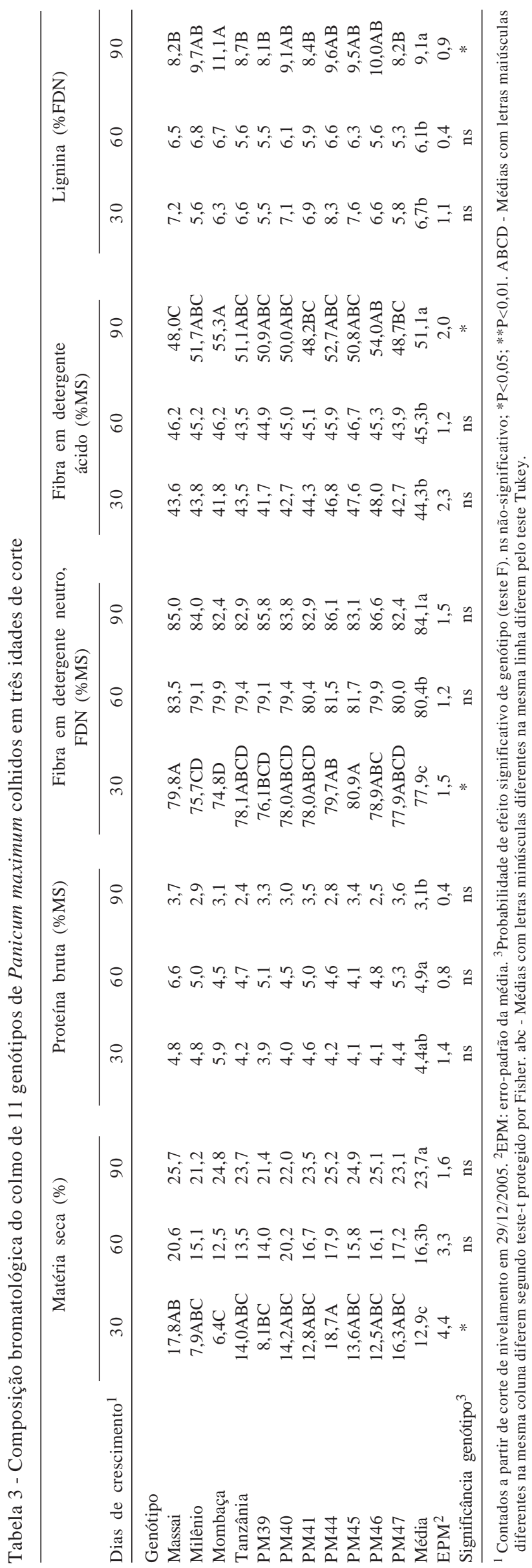

R. Bras. Zootec., v.39, n.7, p.1418-1428, 2010 
(Tabela 3). Na média dos onze genótipos, não houve diferença no teor de lignina do colmo quando colhido com 30 ou 60 dias, contudo houve aumento no conteúdo de lignina do colmo colhido com 90 dias de crescimento (Tabela 3).

Houve diferença entre os genótipos no teor de lignina do colmo somente quando colhidos com 90 dias de crescimento (Tabela 3). Aos 90 dias de crescimento, o cultivar Mombaça apresentou maior concentração de lignina (\%FDN) no colmo do que os cultivares Massai e Tanzânia, e não diferiu do cultivar Milênio (Tabela 3). Os valores de fibra em detergente neutro e lignina determinados para o colmo, e a elevação desses valores com a maturidade, são semelhantes aos reportados para três gramíneas por Wilman \& Moghaddam (1998).

As maiores mudanças que ocorrem na composição química das plantas forrageiras são aquelas que acompanham sua maturação. À medida que a planta envelhece, a proporção dos componentes potencialmente digestíveis tende a diminuir e a de fibras, aumentar. A digestibilidade da parede celular é um dos principais limitadores do desempenho de animais ruminantes em países tropicais (Wattiaux et al., 1991). Assim, é importante a seleção de novas plantas forrageiras que possuam maior digestibilidade da fibra em detergente neutro e que mantenham alta digestibilidade da fibra em detergente neutro mesmo em estágios avançados de maturidade. Colmo e folhas apresentam composição bromatológicas distintas, e a maturidade afeta de maneira diferente as duas frações; sendo assim, é importante que os programas de melhoramento de plantas forrageiras atuem separadamente sobre as duas frações (Wilson, 1993).
Na média dos onze genótipos de capim-colonião estudados, não houve diferença na digestibilidade in vitro da fibra em detergente neutro ou digestibilidade in vitro da matéria seca do colmo quando os genótipos foram colhidos com 30 ou 60 dias, sendo que com 90 dias houve decréscimo em ambos (Tabela 4).

Houve diferença entre os genótipos para a digestibilidade in vitro da matéria seca e digestibilidade in vitro da fibra em detergente neutro em todas as idades de corte, demonstrando o grande efeito genético sobre esse parâmetro (Tabela 4). Entre os cultivares avaliados, o cultivar Massai apresentou um dos menores valores de digestibilidade in vitro da matéria seca e digestibilidade in vitro da fibra em detergente neutro do colmo com 30 dias, porém um dos maiores valores de digestibilidade in vitro da matéria seca e digestibilidade in vitro da fibra em detergente neutro do colmo com 90 dias de crescimento (Tabela 4). Esses resultados demonstram que o capim-massai sofre menor queda da digestibilidade in vitro da fibra em detergente neutro do colmo com o avanço da maturidade do que os demais cultivares testados, no entanto a digestibilidade in vitro da fibra em detergente neutro inicial (30 d) do colmo do capim-massai é baixa. Esse comportamento do capim-massai pode estar associado ao menor alongamento de colmo e à manutenção de maior proporção de folhas após 90 dias de crescimento (Tabela 2).

Os demais cultivares comerciais avaliados apresentaram grande queda na digestibilidade in vitro da fibra em detergente neutro e digestibilidade in vitro da matéria seca de 60 para 90 dias de crescimento (Tabela 4). Dentre os acessos avaliados, o PM39 e o PM47 se destacaram pelos

Tabela 4 - Digestibilidade in vitro do colmo de 11 genótipos de capim-colonião colhidos em três idades de corte

\begin{tabular}{|c|c|c|c|c|c|c|}
\hline \multirow[t]{2}{*}{ Dias de crescimento ${ }^{3}$} & \multicolumn{3}{|c|}{ DIVMS $^{1}$} & \multicolumn{3}{|c|}{ DIVFDN $^{2}$} \\
\hline & 30 & 60 & 90 & 30 & 60 & 90 \\
\hline Massai & $51,9 \mathrm{BC}$ & $52,8 \mathrm{BCD}$ & $43,9 \mathrm{AB}$ & $39,7 \mathrm{BC}$ & 43,4ABCD & $34,0 \mathrm{AB}$ \\
\hline Mombaça & $58,5 \mathrm{~A}$ & $57,9 \mathrm{ABC}$ & $38,9 \mathrm{~B}$ & $44,5 \mathrm{ABC}$ & $47,3 \mathrm{ABC}$ & $25,8 \mathrm{~B}$ \\
\hline Tanzânia & $58,7 \mathrm{~A}$ & 56,1ABCD & $40,8 \mathrm{~B}$ & $47,2 \mathrm{~A}$ & $44,7 \mathrm{ABC}$ & $28,6 \mathrm{~B}$ \\
\hline PM39 & $61,9 \mathrm{~A}$ & $58,8 \mathrm{AB}$ & $47,4 \mathrm{AB}$ & $50,0 \mathrm{~A}$ & $47,9 \mathrm{ABC}$ & $38,8 \mathrm{~A}$ \\
\hline PM44 & $52,5 \mathrm{BC}$ & $51,0 \mathrm{CD}$ & $39,0 \mathrm{~B}$ & $40,4 \mathrm{BC}$ & $40,0 \mathrm{CD}$ & 29,1B \\
\hline PM45 & 49,9C & $56,1 \mathrm{ABCD}$ & $43,5 \mathrm{AB}$ & $38,1 \mathrm{C}$ & $46,0 \mathrm{ABC}$ & $32,1 \mathrm{AB}$ \\
\hline PM46 & $58,7 \mathrm{~A}$ & $48,0 \mathrm{D}$ & 39,7B & $47,8 \mathrm{~A}$ & $34,9 \mathrm{D}$ & $30,7 \mathrm{AB}$ \\
\hline PM 47 & $60,3 \mathrm{~A}$ & $58,5 \mathrm{AB}$ & $50,3 \mathrm{~A}$ & $49,1 \mathrm{~A}$ & $48,1 \mathrm{AB}$ & $39,6 \mathrm{~A}$ \\
\hline Média & $57,1 \mathrm{a}$ & $55,6 \mathrm{a}$ & $42,8 b$ & $45,0 \mathrm{a}$ & 44,9a & $31,9 b$ \\
\hline $\mathrm{EPM}^{4}$ & 2,1 & 2,5 & 2,9 & 2,6 & 2,7 & 3,2 \\
\hline
\end{tabular}

${ }^{1}$ DIVMS: digestibilidade in vitro da matéria seca. ${ }^{2}$ DIVFDN: digestibilidade in vitro da fibra em detergente neutro. ${ }^{3}$ Contados a partir do corte de nivelamento em $29 / 12 / 2005$. ${ }^{4}$ EPM: erro-padrão da média. ${ }^{5}$ Probabilidade de efeito significativo de genótipo (teste F). ns não-significativo; *P<0,05; **P<0,01. ABCD - Médias com letras maiúsculas diferentes na mesma coluna diferem segundo teste-t protegido por Fisher. ab- Médias com letras minúsculas diferentes na mesma linha diferem pelo teste de Tukey. 
altos valores de digestibilidade in vitro da fibra em detergente neutro do colmo em todas as idades e pequena queda na digestibilidade in vitro da fibra em detergente neutro do colmo com o avanço da maturidade (Tabela 4).

Os teores de fibra em detergente neutro e fibra em detergente ácido do colmo, com 90 dias de crescimento, $84,1 \%$ e $51,1 \%$, respectivamente, são semelhantes aos encontrados por Dias et al. (2008), que encontraram 78,5\% para a fibra em detergente neutro e 52,1\% para a fibra em detergente ácido, e esses teores elevados nessa idade podem ser responsáveis pela baixa digestibilidade in vitro da matéria seca do colmo. Em geral, o incremento na fibra em detergente neutro da forragem está associado ao incremento de parede celular, que promove redução na digestibilidade in vitro da matéria seca (Van Soest, 1994; Rêgo, 2003).

Ao contrário do elevado efeito genético sobre a qualidade do colmo, houve pequena variação genotípica quanto à composição bromatológica e digestibilidade de folhas (Tabelas 5 e 6). Os genótipos variaram somente quanto ao teor de lignina (\%FDN) na folha quando colhidos com 90 dias de crescimento (Tabela 5). Dentre os cultivares estudados, o capim-tanzânia apresentou menor teor de lignina (\%FDN) na folha do que o cultivar Milênio, quando colhidos com 90 dias de crescimento (Tabela 5). O menor teor de lignina (\%FDN) da folha do capim-tanzânia colhido com 90 dias de crescimento não resultou em maior digestibilidade in vitro da fibra em detergente neutro com 90 dias de crescimento, entre os onze genótipos estudados (Tabela 6).

Na média dos genótipos, houve aumento linear dos teores de matéria seca, fibra em detergente ácido e lignina de folhas, e redução dos teores de digestibilidade in vitro da matéria seca e digestibilidade in vitro da fibra em detergente neutro com o avanço da maturidade (Tabelas 5 e 6). Quanto ao teor de fibra em detergente neutro de folhas, houve pequeno aumento da concentração entre 30 e 60 dias, seguido por redução do teor de fibra em detergente neutro entre 60 e 90 dias, sendo que não houve diferença entre 30 e 90 dias (Tabela 5).

Da mesma forma que ocorreu no colmo, não houve diferença na porcentagem média de proteína bruta de folhas entre 30 e 60 dias de crescimento e houve queda acentuada de 60 para 90 dias de crescimento (Tabela 5). Não houve variação entre os genótipos estudados quanto ao teor de proteína bruta nas folhas (Tabela 5).

Avaliando-se a correlação entre os componentes da parede celular e a digestibilidade in vitro da matéria seca ou digestibilidade in vitro da fibra em detergente neutro, nota-se que houve forte correlação negativa entre o teor de fibra em detergente neutro e a digestibilidade in vitro

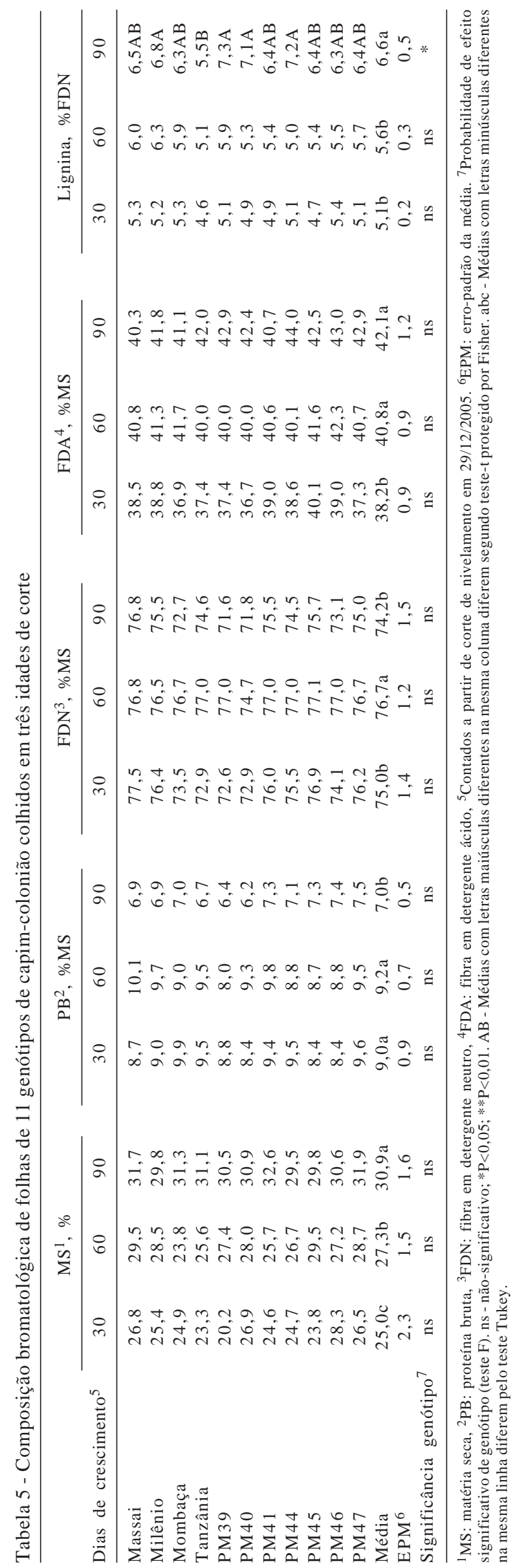

R. Bras. Zootec., v.39, n.7, p.1418-1428, 2010 
Tabela 6 - Digestibilidade in vitro de folhas de 11 genótipos de capim-colonião colhidos em três idades de corte

\begin{tabular}{|c|c|c|c|c|c|c|}
\hline Dias de crescimento ${ }^{3}$ & \multicolumn{3}{|c|}{ DIVMS $^{1}$} & \multicolumn{3}{|c|}{ DIVFDN $^{2}$} \\
\hline Massai & 49,0 & 51,6 & 54,2 & 34,2 & 36,7 & 40,6 \\
\hline Mombaça & 53,5 & 54,3 & 51,0 & 36,6 & 40,4 & 32,6 \\
\hline Tanzânia & 56,2 & 50,6 & 49,1 & 39,8 & 35,8 & 31,5 \\
\hline РМ39 & 58,7 & 45,0 & 53,3 & 43,1 & 28,4 & 36,6 \\
\hline PM44 & 52,7 & 44,1 & 45,1 & 37,2 & 27,4 & 26,0 \\
\hline PM45 & 53,6 & 43,0 & 44,5 & 39,7 & 26,2 & 27,9 \\
\hline PM46 & 56,4 & 52,3 & 51,2 & 41,0 & 38,1 & 33,5 \\
\hline PM4 7 & 49,2 & 52,8 & 42,0 & 33,6 & 38,4 & 22,9 \\
\hline Média & $54,2 \mathrm{a}$ & $49,6 \mathrm{~b}$ & $49,0 \mathrm{~b}$ & $38,8 \mathrm{a}$ & $34,3 \mathrm{ab}$ & $31,6 b$ \\
\hline $\mathrm{EPM}^{4}$ & 3,7 & 4,1 & 4,1 & 5,1 & 5,5 & 5,9 \\
\hline
\end{tabular}

${ }^{1}$ DIVMS: digestibilidade in vitro da matéria seca.

2 DIVFDN: digestibilidade in vitro da fibra em detergente neutro.

${ }^{3}$ Dias de crescimento: são os dias de crescimento da forrageira a contar a partir de corte de nivelamento em 29/12/2005.

4 EPM: erro-padrão da média.

${ }^{5}$ Probabilidade de efeito significativo de genótipo (teste $\mathrm{F}$ ). ns não-significativo; $* \mathrm{P}<0,05 ; * * \mathrm{P}<0,01$.

ab - Médias com letras minúsculas diferentes na mesma linha diferem pelo teste Tukey.

Tabela 7 - Correlação entre composição química e digestibilidade da matéria seca e fibra em detergente neutro de tecidos de 11 genótipos de capim-colonião colhidos em três idades

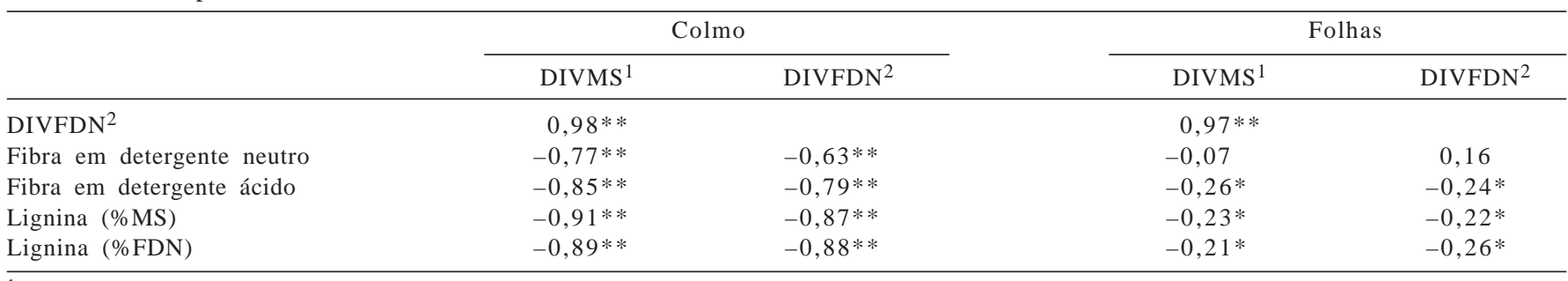

${ }^{1}$ DIVMS: digestibilidade in vitro da matéria seca (30 horas).

2 DIVFDN: digestibilidade in vitro da FDN (30 horas).

da matéria seca do colmo (Tabela 7). O teor de lignina na base da MS (\%MS) e na base da fibra em detergente neutro (\%FDN) foram as medidas bromatológicas melhor correlacionadas com digestibilidade in vitro da matéria seca e digestibilidade in vitro da fibra em detergente neutro do colmo ( $\mathrm{r}=-0,91-\mathrm{P}<0,01$ e $\mathrm{r}=-0,88-\mathrm{P}<0,001$, respectivamente) (Tabela 7 ).

A relação existente entre lignificação e digestibilidade in vitro da fibra em detergente neutro já foi demonstrada anteriormente (Jung \& Allen, 1995). Como a lignina é um componente da parede celular, o efeito da lignina sobre a digestibilidade da forragem é tido como sendo um efeito direto na digestibilidade da fibra, e não da matéria orgânica total da forragem (Van Soest, 1993). Como o teor de fibra em detergente neutro e de lignina estão normalmente correlacionados, pode ocorrer correlação indireta entre \% de lignina na matéria seca e digestibilidade in vitro da matéria seca.

A menor digestibilidade da matéria seca de plantas em estágio avançado de desenvolvimento está normalmente associada com maiores teores de fibra em detergente neutro (Mertens, 1994), no entanto, para a fração folha no presente trabalho, essa relação não existiu (Tabela 7). O decréscimo na digestibilidade in vitro da matéria seca média da fração folha com o avanço da maturidade (Tabela 6) está de acordo com o aumento nos teores médios de fibra em detergente ácido e lignina dessa fração (Tabela 5), entretanto a correlação foi baixa (Tabela 7).

A fraca correlação entre os componentes da parede celular com a digestibilidade in vitro da matéria seca, ou com a digestibilidade in vitro da fibra em detergente neutro, pode ser explicada pela pequena variação genética para esses parâmetros nas folhas. Como observado anteriormente, não houve variação entre os genótipos para nenhum parâmetro avaliado, somente para o teor de lignina aos 90 dias de crescimento (Tabelas 5 e 6).

Alves de Brito et al. (2003) demonstraram a existência de grande variação da digestibilidade in vitro da matéria seca e digestibilidade in vitro da fibra em detergente neutro 
de folhas de Brachiaria brizantha de acordo com a altura de corte, sendo que a porção apical apresentou maior digestibilidade in vitro da matéria seca e digestibilidade in vitro da fibra em detergente neutro do que a porção basal, sem diferir quantos aos valores de fibra em detergente neutro. Esses resultados sugerem que o decréscimo da digestibilidade in vitro da matéria seca de folhas com o avanço da maturidade estaria mais relacionado com o decréscimo na digestibilidade da fibra em detergente neutro pelo processo de lignificação do que com o acúmulo de parede celular. Outros autores encontraram aumento do teor de fibra em detergente neutro das lâminas foliares de gramíneas colhidas com 60 ou 90 dias de crescimento, discordando dos resultados do presente estudo (Wilman \& Moghaddam, 1998).

Comparando-se o colmo e as folhas, nota-se que o colmo teve maiores valores de fibra em detergente neutro e fibra em detergente ácido nas três idades de corte, maiores valores de lignina com 30 e 90 dias de crescimento e menores valores de PB nas três idades de corte (Tabela 8). Todavia, o colmo apresentou maior digestibilidade in vitro da matéria seca com 60 dias de crescimento e maior digestibilidade in vitro da fibra em detergente neutro com 30 e 60 dias de crescimento (Tabela 8). O que se observa é que o avanço da maturidade teve grande efeito sobre a qualidade do colmo, porém pequeno efeito sobre a qualidade da fração folha (Tabela 8).

Com 30 ou 60 dias de crescimento, a digestibilidade da matéria seca e da fibra em detergente neutro do colmo foi igual ou superior à de folhas. Todavia, após 90 dias de crescimento, o colmo apresentou menor digestibilidade in vitro da matéria seca e igual digestibilidade in vitro da fibra em detergente neutro do que as folhas (Tabela 8).

A maior digestibilidade do colmo em estágios iniciais de desenvolvimento pode estar relacionada à maior presença de bainha foliar do que haste nessa fração. Wilman \& Moghaddam (1998) relatam que a bainha foliar da gramínea Festuca arundinacea é mais digestível do que a lâmina foliar, quando a planta é cortada em idade jovem. Wilson (1976) relata que a bainha foliar de gramíneas pode ser mais jovem em desenvolvimento do que suas lâminas foliares e pode ter fraco desenvolvimento de cutícula em bainhas revestidas por lâminas velhas, o que explicaria sua maior digestibilidade. Terry \& Tilley (1964) também encontraram maior digestibilidade da bainha foliar em comparação à lâmina foliar de $F$. arundinacea quando cortada em estágios bem jovens de maturidade, relação que se inverte com o desenvolvimento da planta. Alves de

Tabela 8 - Composição química e digestibilidade in vitro do colmo e de folhas de onze genótipos de capim-colonião colhidos em três idades

\begin{tabular}{|c|c|c|c|c|}
\hline Parâmetro & Dias de crescimento ${ }^{3}$ & Folha & Colmo & $\mathrm{EPM}^{4}$ \\
\hline Matéria seca, \% & $\begin{array}{l}30 \\
60 \\
90\end{array}$ & $\begin{array}{l}25,0 \mathrm{a} \\
27,3 \mathrm{a} \\
30,9 \mathrm{a}\end{array}$ & $\begin{array}{l}12,9 b \\
16,3 b \\
23,7 b\end{array}$ & $\begin{array}{l}0,9 \\
0,9 \\
0,8\end{array}$ \\
\hline Proteína bruta, \%MS & $\begin{array}{l}30 \\
60 \\
90\end{array}$ & $\begin{array}{l}9,0 \mathrm{a} \\
9,2 \mathrm{a} \\
7,0 \mathrm{a}\end{array}$ & $\begin{array}{l}4,4 \mathrm{~b} \\
4,9 \mathrm{~b} \\
3,1 \mathrm{~b}\end{array}$ & $\begin{array}{l}0,4 \\
0,3 \\
0,3\end{array}$ \\
\hline Fibra em detergente neutro, \%MS & $\begin{array}{l}30 \\
60 \\
90\end{array}$ & $\begin{array}{c}75,0 \mathrm{~b} \\
76,7 \mathrm{~b} \\
74,2 \mathrm{~b}\end{array}$ & $\begin{array}{l}77,9 a \\
80,4 a \\
84,1 a\end{array}$ & $\begin{array}{l}0,4 \\
0,5 \\
0,6\end{array}$ \\
\hline Fibra em detergente ácido, \%MS & $\begin{array}{l}30 \\
60 \\
90\end{array}$ & $\begin{array}{c}38,2 b \\
40,8 b \\
42,1 b\end{array}$ & $\begin{array}{l}44,3 a \\
45,3 a \\
51,1 a\end{array}$ & $\begin{array}{l}0,6 \\
0,4 \\
0,7\end{array}$ \\
\hline Lignina, \%FDN & $\begin{array}{l}30 \\
60 \\
90\end{array}$ & $\begin{array}{l}5,1 \mathrm{~b} \\
5,6 \mathrm{a} \\
6,6 \mathrm{~b}\end{array}$ & $\begin{array}{l}6,7 \mathrm{a} \\
6,1 \mathrm{a} \\
9,1 \mathrm{a}\end{array}$ & $\begin{array}{l}0,3 \\
0,2 \\
0,2\end{array}$ \\
\hline DIVMS $^{1}, \% \mathrm{MS}$ & $\begin{array}{l}30 \\
60 \\
90\end{array}$ & $\begin{array}{l}54,2 \mathrm{a} \\
49,6 \mathrm{~b} \\
49,0 \mathrm{a}\end{array}$ & $\begin{array}{l}57,1 \mathrm{a} \\
55,6 \mathrm{a} \\
42,8 \mathrm{~b}\end{array}$ & $\begin{array}{l}1,6 \\
1,1 \\
1,1\end{array}$ \\
\hline DIVFDN $^{2}, \% F D N$ & $\begin{array}{l}30 \\
60 \\
90\end{array}$ & $\begin{array}{l}38,8 b \\
34,3 b \\
31,6 a\end{array}$ & $\begin{array}{l}45,0 \mathrm{a} \\
44,9 \mathrm{a} \\
31,9 \mathrm{a}\end{array}$ & $\begin{array}{l}2,3 \\
1,3 \\
1,6\end{array}$ \\
\hline
\end{tabular}

${ }^{1}$ DIVMS: digestibilidade in vitro da matéria seca.

2 DIVFDN: digestibilidade in vitro da fibra em detergente neutro.

${ }^{3}$ Dias de crescimento a partir do corte de nivelamento em 29/12/2005.

${ }^{4}$ EPM: erro-padrão da média. abc - Médias com letras minúsculas diferentes na mesma linha diferem pelo teste Tukey. 
Brito et al. (2003) relataram que a digestibilidade in vitro da fibra em detergente neutro do colmo de Brachiaria brizantha colhido com 70 dias de crescimento foi superior à de folhas, o que não ocorreu em Brachiaria humidicula.

O fato de o colmo ter melhor digestibilidade in vitro da fibra em detergente neutro do que folhas quando colhidas em até 60 dias têm implicações importantes sobre o manejo das pastagens, bem como sobre os programas de seleção de novos cultivares. É usual a adoção de práticas de manejo e a seleção de novos cultivares focando a manutenção de maior proporção de folhas (Carvalho et al., 2001; Santos et al., 2003). Os resultados aqui apresentados sugerem que, principalmente para sistemas intensivos de exploração de capim-colonião, a digestibilidade do colmo teria maior validade como medida da qualidade da planta do que simplesmente a relação folha:colmo.

Os genótipos mais produtivos normalmente são aqueles que apresentam maior alongamento de colmos. Neste estudo, foi encontrada correlação $(P<0,01)$ entre porcentagem de colmos na matéria seca e produção de matéria seca verde com 60 ou 90 dias de crescimento $(r=0,62$ e 0,56 , respectivamente). A porcentagem de colmo na matéria seca dos cultivares colhidos com 60 e 90 dias se mostrou medianamente correlacionada $(\mathrm{P}<0,01)$ com a digestibilidade in vitro da fibra em detergente neutro do colmo ( $r=-0,51$ e $-0,48$ para 60 e 90 dias, respectivamente). Ou seja, os cultivares com maior proporção de colmos apresentam também colmos de menor digestibilidade da fibra em detergente neutro, porém a correlação não foi forte. Não houve correlação significativa entre produção de matéria seca verde e digestibilidade in vitro da fibra em detergente neutro de colmo com 60 ou 90 dias, e a digestibilidade de folhas não se mostrou correlacionada com qualquer parâmetro produtivo. O interessante para programas de melhoramento seria identificar os genótipos mais produtivos e que apresentem colmos de alta digestibilidade in vitro da fibra em detergente neutro com 60 ou 90 dias. A aplicação de agrupamento por otimização de Tocher utilizando a matriz de distâncias euclidiana média permitiu o estabelecimento de quatro grupos baseados nas variedades medidas com 90 dias de crescimento (Tabela 9).

O grupo 1 representa os genótipos com produção intermediária de matéria seca verde, menor digestibilidade in vitro da fibra em detergente neutro de colmo e menor porcentagem de folhas com 90 dias de crescimento, e foi constituído pelos genótipos Tanzânia, PM46 e PM44. O grupo 2 representa os genótipos com produção intermediária de matéria seca verde, maior digestibilidade in vitro da fibra em detergente neutro do colmo e porcentagem de folhas com 90 dias de crescimento intermediária, e foi constituído pelos acessos PM39 e PM47.

O grupo 3 representa os genótipos com menor produção de matéria seca verde, digestibilidade in vitro da fibra em detergente neutro do colmo intermediária e maior

Tabela 9 - Grupos de genótipos de capim-colonião e média das variáveis em cada grupo

\begin{tabular}{lcccc}
\hline Item & \multicolumn{3}{c}{ Grupo } \\
\cline { 2 - 5 } & 1 & 2 & 3 & 4 \\
& PM44-PM46-Tanzânia & PM39-PM47 & Massai-PM40-PM41-PM45 & Milenium-Mombaça \\
\hline Distância média intragrupo & - & 1,2054 & 1,4389 & 1,8935 \\
PMSV $^{1}$ (kg/ha) & $13.216 \mathrm{ab}$ & $14.389 \mathrm{ab}$ & $11.537 \mathrm{~b}$ & $20.547 \mathrm{a}$ \\
DIVFDN $^{2}$ do colmo (\%FDN) & $29,4 \mathrm{c}$ & $39,2 \mathrm{a}$ & $32,8 \mathrm{~b}$ & $26,6 \mathrm{c}$ \\
Folhas $^{3}$ (\% MS) & $46,6 \mathrm{~b}$ & $50,6 \mathrm{~b}$ & $63,4 \mathrm{a}$ & $50,5 \mathrm{~b}$ \\
\hline
\end{tabular}

${ }^{1}$ PMSV: produção de matéria seca verde com 90 dias, em kg/ha.

2 DIVFDN: digestibilidade in vitro (30 horas) da fibra em detergente neutro do colmo com 90 dias.

3 Porcentagem de folhas na MSV com 90 dias de crescimento.

abc - Médias com letras minúsculas diferentes na mesma linha diferem pelo teste Tukey.

porcentagem de folhas com 90 dias de crescimento, e foi constituído pelos genótipos Massai, PM40, PM41 e PM45. O grupo 4 representa os genótipos com maior produção de matéria seca verde, menor digestibilidade in vitro da fibra em detergente neutro do colmo e porcentagem de folhas com 90 dias de crescimento intermediária, e foi constituído pelos cultivares Milênio e Mombaça. A partir dessa análise verifica-se que os acessos PM39 e PM47 se mostraram genótipos promissores que agregam boa produção de matéria seca verde, boa porcentagem de folhas e alta digestibilidade in vitro da fibra em detergente neutro do colmo com 90 dias de crescimento. 


\section{Conclusões}

Há grande variação entre os genótipos em relação ao efeito da maturidade sobre a digestibilidade do colmo, porém não há efeito dos genótipos sobre a digestibilidade das folhas. A maturidade pouco afeta a digestibilidade de folhas, se comparadas ao colmo. Quando a participação de colmo no total de massa seca aumenta, esse componente passa a ser o limitador da qualidade de plantas forrageiras. Portanto, em programas de melhoramento, deve-se considerar não somente a relação folha:colmo, mas também a digestibilidade in vitro da FDN do colmo para seleção de genótipos.

\section{Referências}

AGUIAR, R.S.; VASQUEZ, H.M.; SILVA, J.F.C. Produção e composição químico-bromatológica do capim-furachão (Panicum repens L.) sob adubação e diferentes idades de corte. Revista Brasileira de Zootecnia, v.29, n.2, p.325-333, 2000.

ALVES DE BRITO, C.G.F.; RODELLA, R.A.; DESCHAMPS, F.C. Chemical profile of cell wall and its implications on Brachiaria brizantha and Brachiaria humidicola digestibility. Revista Brasileira de Zootecnia, v.32, p.1835-1844, 2003.

ASSOCIATION OF OFFICIAL ANALYTICAL CHEMISTS AOAC. Official methods of analysis. 10.ed. Washington: AOAC International, 1980. 1015p.

BARBOSA, R.A.; NASCIMENTO JR., D.; EUCLIDES, V.P.B. et al. Características morfogênicas e acúmulo de forragem do capim-tanzânia (Panicum maximum Jacq. cv. Tanzânia) em dois resíduos forrageiros pós-pastejo. Revista Brasileira de Zootecnia, v.31, n.2, p.583-593, 2002.

BRÂNCIO, P.A.; EUCLIDES, V.P.B.; NASCIMENTO JR., D. et al. Avaliação de três cultivares de Panicum maximum Jacq. sob pastejo: disponibilidade de forragem, altura do resíduo póspastejo e participação de folhas, colmos e material morto. Revista Brasileira de Zootecnia, v.32, n.1, p.55-63, 2003.

CARVALHO, P.C.F.; RIBEIRO FILHO, H.M.N.; POLI, C.H.E.C. et al. Importância da estrutura da pastagem na ingestão e seleção de dietas pelo animal em pastejo. In: MATTOS, W.R.S. (Ed.) Produção animal na visão dos brasileiros. Piracicaba: FEALQ, 2001. p.853-871.

CECATO, U.; MACHADO, A.O.; MARTINS, E.N. et al. Avaliação da produção e de algumas características da rebrota de cultivares e acessos de Panicum maximum Jacq. sob duas alturas de corte. Revista Brasileira de Zootecnia, v.29, n.3, p.660-668, 2000 .

CRUZ, C.D.; REGAZZI A.J. Modelos biométricos aplicados ao melhoramento genético. 2.ed. Viçosa, MG: UFV, 1997, $390 \mathrm{p}$.

DIAS, F.J.; JOBIM, C.C.; BRANCO, A.F. et al. Efeito de fontes de fósforo sobre a digestibilidade in vitro da matéria seca, da matéria orgânica e nutrientes digestíveis totais do capimmombaça (Panicum maximum Jacq. Cv. Mombaça). Semina: Ciências Agrárias, v.29, n.1, p.211-220, 2008.

DIFANTE, G.S; NASCIMENTO JR., D.; EUCLIDES, V.P.B. et al. Sward structure and nutritive value of tanzânia guineagrass subjected to rotational stocking managements. Revista Brasileira de Zootecnia, v.38, n.1, p.9-19, 2009.

EMPRESA BRASILEIRA DE PESQUISA E AGROPECUÁRIA EMBRAPA. Centro Nacional de Pesquisa de Solos. Sistema brasileiro de classificação de solos. Brasília: EMBRAPA, 1999. 412p.
EUCLIDES, V.P.B.; MACEDO, M.C.M.; ZIMMER, A.H. et al. Avaliação dos capins mombaça e massai sob pastejo. Revista Brasileira de Zootecnia, v.37, n.1, p.18-26, 2008.

EUCLIDES, V.P.B. Produção animal em sistema intensivo combinado de pastagens tanzânia e braquiárias na região dos Cerrados. Campo Grande: EMBRAPA-CNPGC, 2001. p.13. (EMBRAPA. Programa Produção Animal. Subprojeto 06.0.99.188.01).

GOERING, H.K.; VAN SOEST, P.J. Forage fiber analysis: apparatus reagents, procedures and some applications. Washington, DC: USDA, 1970. 379p. (Agricultural Handbook).

HACKER, J.B.; MINSON, D.J. The digestibility of plant parts: review article. Herbage Abstracts, v.51, p.459-482, 1981.

HERRERA, R.S. Stem and leaf contribution to the chemical composition of cynodon dactylon cv. coast cross 1. Cuban Journal of Agricultural Science, v.13, p.307-314, 1979.

JANK, L.; SAVIDAN, Y.H.; SOUZA, M.T. de et al. Avaliação do germoplasma de Panicum maximum introduzido na África. 1. Produção forrageira. Revista Brasileira de Zootecnia, v.23, n.3, p.433-440, 1994.

JUNG, H.G.; ALLEN, M.S. Characteristics of plant cell walls affecting intake and digestibility of forages by ruminants. Journal of Animal Science, v.73, p.2774-2790, 1995.

MERTENS, D.R. Regulation of forage intake. In: FAHEY JR., G.C.; COLlins, M.; MERTENS, D.R. et al. (Eds.). Forage quality, evaluation and utilization. Madison: American Society of Agronomy, 1994. p.450-492.

QUADROS, D.G.; RODRIGUES, L.R.A.; FAVORETTO, V. et al. Componentes da produção de forragem em pastagens dos capins tanzânia e mombaça adubadas com quatro doses de NPK. Revista Brasileira de Zootecnia, v.31, n.3, p.1333-1342, 2002.

RÊGO, F.C.A.; CECATO, U.; DAMASCENO, J.C. et al. Valor nutritivo do capim-tanzânia (Panicum maximum Jacq cv tanzânia-1) manejado em alturas de pastejo. Acta Scientiarum Animal Sciences, v.25, n.2, p.363-370, 2003.

REIS, R.A.; RODRIGUES, L.R.A. Valor nutritivo de plantas forrageiras. Jaboticabal: UNESP/FUNEP, 1993. 26p.

RODRIGUES, L.R.A. Espécies forrageiras para pastagens. In: SIMPÓSIO SOBRE MANEJO DA PASTAGEM, 8., Piracicaba, 1986. Anais... Piracicaba: FEALQ, 1986. p.375-387.

RODRIGUES, A.L.P.; SAMPAIO, I.B.M.; CARNEIRO, J.C. et al. Degradabilidade in situ da matéria seca de forrageiras tropicais obtidas em diferentes épocas de corte. Arquivo Brasileiro de Medicina Veterinária e Zootecnia, v.56, n.5, p.658-664, 2004.

SANTOS, P.M.; BALSALOBRE, M.A.A.; CORSI, M. Morphogenetic characteristics and management Tanzânia grass. Pesquisa Agropecuária Brasileira, v.38, n.8, p.991-957, 2003.

SOUZA, F.H.D. Panicum maximum in Brazil. In: LOCH, D.S.; FERGUSON, J.E. (Eds.) Forage seed production. Tropical and subtropical species. New York: CABI, 1999. v.2, p.363-370.

STATISTICAL ANALYSIS SYSTEM - SAS. User's guide. Version 8.2 ed. Cary: SAS Institute, 2000. 235p.

STEEL, R.G.D.; TORRIE, J.H. Principles and procedures of statistics. 2.ed. New York: McGraw-Hill, 1980. 633p.

TERRY, R.A.; TILLEY, J.M.A. The digestibility of the leaves and stems of perennial ryegrass, cocksfoot, timothy, tall fescue, Lucerne and sainfoin, as measured by an in vitro procedure. Grass and Forage Science. v.19, n.4, p.363-372, 1964.

THIAGO, L.R.L.S.; GILL, M. Consumo voluntário de forragem por ruminantes: mecanismo físico ou fisiológico. Revista da Sociedade Brasileira de Zootecnia, v.19, p.47-48, 1990.

VAN SOEST, P.J. Cell wall matrix interactions and degradationsession synopsis. In: JUNG, H.G.; BUXTON, D.R.; HATFIELD, R.D. et al. (Ed.). Forage cell wall structure and digestibility. Madison: American Society of Agronomy, 1993. p.377-393. 
VAN SOEST, P.J. Nutritional ecology of the ruminant. Ithaca: Cornell University Press, 1994. 476p.

WATTIAUX, M.A.; MERTENS, D.R.; SATTER, L.D. Effect of source and amount of fiber on kinetics of digestion and specific gravity of forage particles in the rumen. Journal of Dairy Science, v.74, p.3872-83, 1991.

WILMAN, D.; MOGHADDAM, P.R. In vitro digestibility and neutral detergent fiber and lignin contents of plant parts of nine forage species. Journal of Agricultural Science, v.131, p.51-58, 1998.
WILSON, J.R. Organization of forage plant tissues. In: JUNG, H.G.; BUXTON, D.R.; HATIFIELD, R.D. et al. (Eds). Forage cell wall structure and digestibility. Madison: American Society of Agronomy, Crop Science Society of America, Soil Science Society of America, 1993. p.1-32.

WILSON, J.R. Variation of leaf characteristics with level of insertion on a grass tiller. I. Development rate, chemical composition, and dry matter digestibility. Australian Journal of Agricultural Research, v.27, n.3, p.343-354, 1976. 